\title{
THE INTERNATIONAL CONDITIONS OF UKRAINIAN-POLISH CROSS-BORDER COOPERATION
}

\author{
SVITLANA PYSARENKO, IRYNA NASLIDNYK \\ Faculty of International Relations \\ Ivan Franko National University of Lviv \\ Vul. Sichovyh Striltsiv, 19, Lviv, Ukraine, 79000 \\ e-mail: prosvetka@mail.ru iryna_naslidnyk@yahoo.com
}

\begin{abstract}
After EU enlargement and its approaching to the Ukrainian borders, the development of cross-border cooperation with neighbor countries-members of EU has become extremely important. The integration processes shift from national to the regional and local levels.

The Ukrainian-Polish cross-border cooperation should be aimed at: the intensification of European integration due to the development of the long-term Ukrainian-Polish relations on the innovative basis; the elimination of the institutional obstacles for the structure changes in Ukrainian economy by means of the implementation of the European standards of economic activities; the providing of the maximum possible mobility of technologies, capitals, labor, goods and services; the coordination of strategic programs for boundary regions development in order to enhance their competitive advantages. The cross-border cooperation is restrained by the barriers, such as: political, economical, infrastructural, legal, organizational, social. The current state of the Ukrainian-Polish cross-border cooperation shows that both in Poland and Ukraine there is a need for assuming the complex political, economical, technical, organizational and ecological measures which have to minimize the negative exposures of existing barriers. The boundary situation of regions should be taken as an advantage for social-economy development that has to facilitate the transit potential of the border territories.

Key words: cross-border cooperation; free movement of persons, commodities, services and capital; political, economic, infrastructural, legal, organizational and technical barriers; investment cooperation; foreign trade; boundary transportation infrastructure; cross-border cooperation of higher educational institutions and enterprises
\end{abstract}

\section{INTRODUCTION}

After EU enlargement and its approaching to Ukrainian borders the development of cross-border cooperation with our neighbours-members of EU requires the special attention. There is the gradual transferring of integration processes from central on regional and local levels. 
The Ukrainian-Polish cross-border cooperation plays a complementary, supplementary part in the implementation of Ukrainian euro-integration strategy, generating the synergistic effects of joint engagement, assisting in the democracy and pluralism development, overcoming the national antagonism, developing the subsidiary state.

The main object of Ukrainian-Polish cross-border cooperation must be:

- deepening the EU integration through the development of long duration Ukrainian-Polish relations on innovative basis;

- removing the institutional barriers for the structural changes in the Ukrainian economy due to the implementation of the European norms of economic activity; - providing for the highest mobility of technologies, capital, commodities, services, labour;

- coordinating the strategic programs of boundary regions development with the purpose of their competitiveness strengthening.

In the current context the Ukrainian-Polish border fulfils a contact function. It is necessary for the perspective border cooperation to be built on the basis of integration model which stipulates the creation of the region of cross-border cooperation with a free movement of commodities, services, capital, people.

Such policy provides for greater transparency of the borders establishing not only the dissociation - that is the mutual penetration of borders and the formation of the common units-but also greater cooperation of neighbour countries.

Its realization is slowed by the barriers such as: political, economic, infrastructural, legal, organizational, public drawbacks.

Political barriers are attributed to the Polish entering the EU, especially with its joining the Schengen zone that has considerably influenced the character of the cross-border cooperation of Ukraine and Poland. The analysis of Ukrainian-Polish cross-border cooperation testifies that the strengthening of the control and barrier functions of border on the new the legal base of the Schengen agreement has a contradictory influence on the level of openness and safety, as well as on the further development of cross-border cooperation.

\section{SOCIAL, ECONOMICAL AND INFRASTRUCTURAL POLISH-UKRAINIAN RELATIONS}

In April-May 2007 the sociological research "The new East border of European Union: question of transparent, safety and cross-border cooperation (Poland Slovakia - Hungary - Ukraine)" was carried out within the framework of project "The centre of Ukrainian-Polish initiatives: the creation of stable platform for the development of boundary territories". 712 respondents from Lviv and Zakarpattia oblast's of Ukraine, Lubelskie and Podkarpackie voivodships of Poland were questioned. 
When asked "How has the Polish enter to the European Union influenced the development of Polish-Ukrainian cooperation?" 64.4\% inhabitants of Ukraine and Poland returned an positive answer. When asked "How will Polish joining the Schengen agreement affect the possibility of visas receiving for the Ukrainian citizens?" $42.8 \%$ of Ukrainians and $25.2 \%$ of Poles answered "rather negatively than positively" or "negatively". When asked "What is it needed to be done for the improvement of Frontier Service?" 29.9\% of Ukrainians and 35.1\% of Poles answered that it is necessary to increase the allowances for arrangement of borders according to European standards. (Tokar 2008).

The Polish membership in the Schengen zone is aimed to the free movement of persons, commodities, services and capital between EU members and their neighbours. There was a dilemma in Poland: from the one side it is necessary to provide the protective functions of border, and from other, to facilitate the motion of people, commodities and services. The realization of the first function resulted in the strengthening of control on the external borders of Poland, which are simultaneously the external borders of EU. But Poland was not succeeded in solving the second problem. As a result the social mobility of Ukrainian citizens has considerably reduced; transparency of border has substantially decayed. "The Iron Curtain" has become perceptible more than ever after disintegration of the USSR.

The obstacles in Ukrainian-Polish cooperation are visas, customs duties, custom limitations, system of certification and standardization for the some groups of commodities. The existent visa policy is the real challenge for Polish-Ukrainian cross-border cooperation. Its present condition cramps economic, public, professional and private contacts, and detains cross-border cooperation.

After Poland entering the Schengen area the conditions of visa granting has become severe. In spite of Poland's reconstructing its consulates network in Ukraine (Kyiv, Kharkiv, Lviv, Lutsk, Odessa), the problem of visa granting remains very acute. For example, in 2008 the Consulate General of the Republic of Poland in Lviv has given out 199 thousand of visas. But at the same time the share of multiple visas has considerably reduced. The abolition of previous record for documents submission in the Internet caused large round-the-clock queues in consulates. The existent visa policy has resulted in the reduction of possibilities to drive out to Poland even having all necessary documents.

Among many problems in the development of cross-border cooperation, the economic development disproportions in regions on both sides of border and considerable level of divergence of boundary regions of Poland and Ukraine are one of acutest.

The characteristic sign of the Polish voivodships and Ukrainian oblast's is a lower level of their social-economic development against the average country indexes-71\% (Kowerski, Matkowski 2006).

To the economic barriers we refer a different degree and character of market transformations in economies of Poland and Ukraine, different level of socially-economic development. In 2008 Ukrainian GDP was 180 billion \$, Polish GDP—528 
billion \$. GDP per capita was 3909 \$ and 13846 \$ respectively (World Economic... 2009). There is a considerable difference in unemployment level, labour migration, and development of private sector rates (Table 1).

Table 1. Social and Economic Development of Ukrainian-Polish Cross-Border Region (2007)

\begin{tabular}{|l|c|c|}
\hline \multicolumn{1}{|c|}{ Indexes } & Lviv Oblast' & Podkarpackie Voivodeship \\
\hline Area, $\mathrm{km}^{2}$ & 21800 & 17800 \\
\hline Population, million person & 2.5 & 2.1 \\
\hline Structure of labor force: & & 23.5 \\
\hline $\begin{array}{l}\text { - agriculture, hunting, } \\
\text { forestry and fisheries } \%\end{array}$ & 3.6 & 29.2 \\
\hline \multicolumn{1}{c}{ - industry and construction, \% } & 23.5 & 47.3 \\
\hline \multicolumn{1}{c}{ - services, \% } & 64.5 & 14.2 \\
\hline Level of unemployment, \% & 7.7 & 813 \\
\hline Average wages per month, \$ & 234 & 6843 \\
\hline $\begin{array}{l}\text { Gross regional product } \\
\text { per capita, \$ }\end{array}$ & 2161 & \\
\hline
\end{tabular}

Source: The State Committee of Statistics of Ukraine. <http://www.stat.lviv.ua/ukr/si/ inf_2009.php?ind_page $=$ si $>$; Regional Data Bank of the Central Statistical Office of Poland.

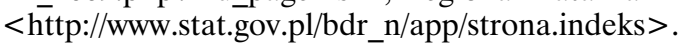

Agriculture has considerable part in the structure of added value of Ukrainian border regions in comparative with Polish (Table 2).

Table 2. Structure of Added Value of Ukrainian-Polish Cross-Border Region, \% (2007)

\begin{tabular}{|l|c|c|}
\hline \multicolumn{1}{|c|}{ Economic activities } & Lviv Oblast & Podkarpackie Voivodeship \\
\hline Total & 100 & 100 \\
\hline $\begin{array}{l}\text { Agriculture, hunting, forestry } \\
\text { and fisheries }\end{array}$ & 10.4 & 3.1 \\
\hline Industry & 23.2 & 26.8 \\
\hline Construction & 6.1 & 6.2 \\
\hline Services & 60.3 & 63.8 \\
\hline
\end{tabular}

Source: Baza danih "Regiostat"—Golovne ypravlinnâ statistki y L'vivs'kij oblasti, <http://stat6. stat.lviv.ua/PXWEB2006p/dialog/statfile1_r.asp>; Rocznik Statystyczny Województwa Podkarpackiego 2008, Urząd Statystyczny, R̄zeszów <http://www.stat.gov.pl/cps/rde/xbcr/rzesz/ ASSETS_08w22_01.pdf>.

In obedience to the conclusions of European Commission, the distortion of boundary regions development is determined by the level of their innovative systems.

The comparison of the Podkarpackie Voivodship and Lviv Oblast' testifies that high innovative potential has the Podkarpackie Voivodship, and the Lviv Oblast' has the lowest innovative potential in Ukraine. 
The boundary regions of Poland and Ukraine are poorly urbanized. They have own limited financial possibilities, including in particular costs for realization of common projects, small amounts of direct foreign investments, poorly developed bank infrastructure and private enterprise.

The inflow of direct foreign investments from Poland to Ukraine plays an important role in development Ukrainian-Polish cross-border cooperation. Their amount is small yet, but with every year they tend to grow (Table 3).

Table 3. Ukrainian-Polish Investment Cooperation (2001-2008)

\begin{tabular}{|l|c|c|c|c|c|c|c|c|}
\hline \multirow{2}{*}{\multicolumn{1}{|c|}{ Indexes }} & \multicolumn{7}{c|}{ Years } \\
\cline { 2 - 10 } & 2001 & 2002 & 2003 & 2004 & 2005 & 2006 & 2007 & 2008 \\
\hline $\begin{array}{l}\text { Investments from Poland } \\
\text { to Ukraine, million \$ }\end{array}$ & 69.3 & 98.4 & 153.3 & 179.5 & 224.0 & 366.0 & 670.5 & 694.7 \\
\hline Number of interprises & 710 & 791 & 861 & 942 & 1027 & 1087 & 1238 & 1244 \\
\hline $\begin{array}{l}\text { Investments from Ukraine } \\
\text { to Poland, million \$ }\end{array}$ & 0.3 & $0, .3$ & 0.4 & 0.3 & 21.3 & 24.2 & 30.1 & 46.9 \\
\hline Number of interprises & 7 & 8 & 7 & 7 & 7 & 8 & 8 & 9 \\
\hline
\end{tabular}

Source: Pol'ša-Ukraina: Investicijne spivrobitnictvo. Deržavna podtrimka ukrains'kogo eksportu, <http://www.ukrexport.gov.ua/ukr/analiz_inv_spivirobnictva/pol/341.html>.

At the beginning of 2009 the capital of the Polish investors in Ukraine reaches 694.7 \$ million (1.9\% from the total value foreign direct investments) according the State Committee of Statistics of Ukraine. There are 1244 enterprises with Polish capital in Ukraine.

Ukrainian investments in Polish economy was 46.9 million \$ in 2008 (0.8\% from the total value foreign direct investments). There are 9 enterprises with Ukrainian capital in Poland.

Traditionally Polish investments directed in manufacturing industry (about 60\%), financial sector (about 20\%), wholesale and retail trade (about 12\%).

The main obstacles for direct foreign investments to Ukraine are: the vagueness of legislation and priorities of national economy development; the insolvency of government to abide the obligations incurred; the unsatisfactory development of a transport infrastructure and telecommunication network; corruption (Mihasjuk, Zaloga, Suhaj 2008).

The moving of goods and services across Ukrainian-Polish border has a considerable dynamics changes. In the beginning of the 90th the turnover between Ukraine and Poland was near 200 million \$ (Table 4). Till 1997 it was observed increasing of sales volumes, and the Ukrainian-Polish foreign trade turnover was 930 million \$ in 1997. After that the trade volume in the bilateral Ukrainian-Polish relations was decreased. Just only in 2001 it was reached to the level of 1997. And from this period the trade turnover between Ukraine and Poland run away. It was 6.6 billion $\$$ in 2008. The balance of Ukrainian trade with Poland is negative. It was increased more 
than 100 times till 1.9 million \$ from 2002 to 2008 . It is explained by non-optimal export structure, imperfect export stimulation, insufficient using of export potential in the Ukrainian boundary regions.

Table 4. Ukrainian-Polish Trade Indexes (1993-2008)

\begin{tabular}{|c|c|c|c|c|c|c|c|c|}
\hline \multirow{2}{*}{ Years } & \multicolumn{2}{|c|}{ Export } & \multicolumn{2}{c|}{ Import } & \multicolumn{2}{c|}{$\begin{array}{c}\text { Figures } \\
\text { foreign trade }\end{array}$} & Balance, & Export/ \\
\cline { 2 - 8 } & million \$ & $\begin{array}{c}\text { \% to } \\
\text { previous } \\
\text { year }\end{array}$ & million \$ & $\begin{array}{c}\text { \% to } \\
\text { previous } \\
\text { year }\end{array}$ & million \$ & $\begin{array}{c}\text { \% to } \\
\text { previous } \\
\text { year }\end{array}$ & million \$mport & \\
\hline 1993 & 122.5 & 100 & 76.8 & 100 & 199.3 & 100 & 45.7 & 1.60 \\
\hline 1994 & 197.6 & 161.3 & 189.1 & 246.2 & 386.7 & 194 & 8.5 & 1.04 \\
\hline 1995 & 256.8 & 130 & 457.8 & 242.1 & 714.6 & 184.8 & -201 & 0.56 \\
\hline 1996 & 362.8 & 141.3 & 510.7 & 111.6 & 873.5 & 122.2 & -147.9 & 0.71 \\
\hline 1997 & 380.3 & 104.8 & 549.9 & 107.7 & 930.2 & 106.5 & -169.6 & 0.69 \\
\hline 1998 & 317.9 & 83.6 & 478.2 & 87 & 796.1 & 85.6 & -160.3 & 0.66 \\
\hline 1999 & 301.4 & 94.8 & 258.5 & 54.1 & 559.9 & 70.3 & 42.9 & 1.17 \\
\hline 2000 & 417.9 & 138.7 & 312.5 & 120.9 & 730.4 & 130.5 & 105.4 & 1.34 \\
\hline 2001 & 489.2 & 117.1 & 447 & 143 & 936.2 & 128.2 & 42 & 1.09 \\
\hline 2002 & 508.4 & 103.9 & 526.7 & 150.9 & 1035.1 & 110.6 & -18.3 & 0.97 \\
\hline 2003 & 770.1 & 151.5 & 794.7 & 150.9 & 1564.8 & 151.2 & -24.6 & 0.97 \\
\hline 2004 & 979.9 & 128.42 & 968.8 & 120.72 & 1948.7 & 124.5 & 11.1 & 1.01 \\
\hline 2005 & 1010.9 & 103.2 & 1406.7 & 139.5 & 2417.6 & 124.1 & -395.8 & 0.72 \\
\hline 2006 & 1344.5 & 133.0 & 2109.2 & 149.9 & 3453.7 & 142.9 & -764.7 & 0.64 \\
\hline 2007 & 1636.9 & 121.8 & 2920.5 & 138.5 & 4557.4 & 131.9 & -1283.6 & 0.56 \\
\hline 2008 & 2338.3 & 142.8 & 4280.3 & 146.6 & 6618.6 & 145.2 & -1942 & 0.54 \\
\hline
\end{tabular}

Source: calculated using the State Committee of Statistics of Ukraine.

Poland's joining the Schengen zone caused the considerable slump of the boundary haggling in the form of "shuttle" business in Ukraine. The primitive form of cross-border trade has died off, resulting in the loss of profits for considerable part of population in Ukrainian boundary regions and as well to the growth of unemployment, because of liquidation of some trade personnel which served the Ukrainian market on territory of Poland (wholesale stores, shops, markets).

The question at issue is how quickly "shuttle" business will be replaced by the civilized forms of cross-border trade, due to private sector transition on innovative basis on both sides of border.

The establishment of the civilized international trade contacts between Ukrainian and Polish boundary enterprises is provided by the participation in international exhibitions and fairs which are leaded on the territory of both countries. 
The structure of cross-border regions has a bipolar plan framework, which is conditioned by the forming of agglomeration pair of cities-centres on two sides of Ukrainian-Polish boundary. They are located on cross-border plan axescross-border corridors (Lviv - Rzeszow, Kovel - Chelm). They have status "poles of growth".

The Polish area of EU border with Ukraine is equal to $526.3 \mathrm{~km}$. The insufficient development of infrastructure is a barrier negatively influencing the increase of cross-border streams because of the unsatisfactory roads across the border, and insufficient amount of the involved boundary transitions points.

Poland with Ukraine is connected by 11 hard-surface roads (three of them don't have boundary transition points) and seven railway ways. An existent network has become an organizational and technical barrier, because of the track width. In addition negative influence on the volumes of railway transportations has the rise of price on railroad tickets and the competition from the side of more cheap and ramified bus connections.

There is an insufficient amount of car and pedestrian points of admission- 6 altogether. According to information of government boundary service of Ukraine, existing transitions provides for the crossing of 8 thousand cars on a day. Actually more than 13 thousand cars a day move across boundary transitions, which lead to large turns and stimulates the corruption in the points of crossing of state boundary. For 2004-2006 on a Carpathian area of the Polish-Ukrainian border the goods contraband on 9.4 million PLN is discovered (Krol M. and Krol P. 2008).

Every year the streams of people and transport vehicles which cross Ukrainian-Polish border are increasing. In 2001 there were 10.0 million people and 2.5 million vehicles, and in 2006-18.0 million people and 6.0 million vehicles. The analysis of chain indexes of dynamics of persons movement across the border for 2004-2007 testify that the growth of border crossing by the Poland's citizens riding into Ukraine are twice higher then the analogical index for foreigners who arrive to Poland.

The development of Ukrainian-Polish cross-border cooperation is impossible without the including to the international system of transport corridors and the forming of boundary infrastructure, which promotes the increase of transportations volumes.

An important cross-border corridor on Ukrainian-Polish border is a primary multifunction territorial communication centre (railway and automobile) which includes three transitions: Mostiska - Przemysl, Shegini - Medyka, and Krakovets - Korczowa.

A multifunction role has also "corridor" with railway and automobile transitions: Rava-Ruska - Hrebenne and Yagodin - Dorohusk.

The Ukrainian-Polish cross-border cooperation is largely determined by such transit transport corridors as east-west (E40) and north-south (Via Intermare). The territory of Ukraine and Poland have also transport corridors No3 (Kiev - Berlin, a length is a $1640 \mathrm{~km}$ ) and "Baltic - Black See" (Odessa - Gdansk). Each of these corridors has a territory of $200 \mathrm{~km}$ crosswise steaming direction and no less than two types of transport. 
Both the road spacing and the road technical state influence the intensity of cross-border people and transport moving. The index of cross-border road spacing is very low and makes $47.8 \mathrm{~km}$ while the average value in Poland is $22.5 \mathrm{~km}$ (Fedan 2008). Among 11 roads crossing the Ukrainian-Polish border only 4 is of improved standard. Moreover, the characteristic of the cross-border travelling system is an absence of near-border roads with vertical direction, especially from the Polish side.

The infrastructure does not meet the requirements of European football championship-2012 prepared by Ukrainian and Poland. An obstacle for railway crossborder movement development is incompatibility of the railway systems of both countries, because of the difference in the parameters of track width. The necessity of undercarriage change at the station Przemyśl complicates the transportation of both people and loads.

There is a necessity to realize the complex of political, economic, technical, organizational, ecological measures by both Poland and Ukraine, which would minimize the negative influence of existent barriers on development of Ukrainian-Polish cross-border cooperation. The near-border situations of regions on both sides of border must be used as a competitive edge for their social and economic development promoting the realization of transit potential of boundary territories. Ukraine has the greatest transit potential in Europe. Data of RENDEL institute show that it amounts to $3.75 \%$.

The researches testify that the augmentation of cross-border streams might be due to the increase of cross-border cooperation efficiency, minimization of transaction charges. Thus, the countries accommodating European transport corridor No3 (Berlin - Dresden - Wroclaw - Lviv - Kyiv) work actively for the increase of traffic capacity, the modernization of its infrastructure, the improving of load documenting. It must result in the simplification of load registration procedure, its customs and boundary inspections and therefore in the growth of transportations speed.

A great importance for the augmentation of cross-border car streams will have a motorway of A-4. It is a travelling communication axis, from west to east, which will provide connection of Western Europe with Ukraine and will meet the plan of preparation to the organization of EURO-2012.

In 2006 the Government of Ukraine approved the Conception of Complex Program of organization and reconstruction of state boundary on a period till 2015.

From the Ukrainian side the simplification of boundary crossing are taking place, inter alia, the introduction of modern European control technologies, the optimization of minimum time standards of control procedures, the introduction of separate traffic lane-_"green corridor".

In accordance with Program, the volumes of annual transportations through the automobile pass points in Rava-Ruska, Krakovets, Shegini till 2015 year could be increased up to 5853.5 thousand ton of cargo and 41861.3 thousand of passengers; corridor No3-145.2 million ton, corridor No5-84.6 million ton, corridor No9-155.5 million ton (data of the Western regional custom office). 
The Baltic - Black See transport corridor is perspective, but not fully mastered yet. With the purpose of establishment of direct communications between ports Odessa and Gdansk, it is necessary for greater attractiveness of this route to harmonize the price policy of countries-participants in the field of tariffs on railway and marine transport.

The development of tourism is negatively influenced by the unsatisfactory tourist base, quality of services, state of all tourist infrastructures. At the same time the tourist, recreation, scientific and educational resources are an upcoming trend of cooperation on Ukrainian-Polish near-border line with its very attractive tourist and natural territories.

The development of cross-border cooperation in the field of tourism and recreation provides for forming the common competitive tourist products-i.e. common cross-border excursions and tourist routes.

The geographical neighbourhood requires the coordinated actions for environment protection, which provide for: monitoring the cross-border transfer of air and water contaminations, developing the general program for their diminishing; protecting the plants, animals and mineral resources; controlling the transit of industrial wastes through the territory of regions.

The development of cross-border cooperation promotes the harmonization of relations in the different areas. There are cross-border structures, which have an interregional development tasks. The activation of Ukrainian-Polish cross-border cooperation often results in dissociation - that means the mutual penetration of regions and the formation of the common units (Euroregions, euro-areas, bilateral or multilateral techno parks, clusters, etc).

Among the 17 Euroregions existing on the scopes of Poland, two- "Bug" and "Carpathian Euroregion"- take part in the Ukrainian-Polish cooperation. The trilateral program of Ukraine - Poland - Belarus neighbourhood financed from the EU budget will be also realized (in 2007-2013 within the framework of European Neighbourhood Policy Instrument-ENPI). The association "Carpathian Euroregion-Poland", which executes the function of national representative office of Poland in the Carpathian Euroregion together with Euro-regional Informative Centre, is engaged in bringing wide circle of institutions in to the cross-border cooperation.

The important instrument of modernization of cross-border regions is a cooperation of higher educational institutions and enterprises from both border sides to form the cross-border clusters using experience of existent clusters and cluster initiatives in Polish and in Ukrainian border line. The basic development directions of cross-border clusters are the organization of common innovative researches, seminars, marketing measures, general network for information exchange.

In reliance on high scientific potential of institutes and enterprises in Ukrainian-Polish boundary regions, the forming of "technopolises" on the base of academic organizations, sectoral scientific experimental institutes on both sides of border is proposed. 


\section{CONCLUSIONS}

The priorities of investment and innovative strategy of Ukrainian-Polish cross-border cooperation are:

- creation of information analytical centres on both sides of border;

- concentration of boundary resources for the fundamental and applied researches;

- introduction of program-purposive approach to innovative cross-border activity;

- expanded participation of small and middle business in innovative activity on the basis of knowledge and experience exchange; managers and hired workers training; the collaboration of the Polish specialists with the Ukrainian colleagues.

The development of cross-border cooperation in social and cultural sphere provides for the organization of Polish festivals in Ukraine and Ukrainian in Poland, scientific cooperation on the basis of exchange with research workers and students, creation of common educational and scientific experimental establishments.

The development of cross-border cooperation must also comprise:

- measures for liquidation of abuses, fight against corruption, crimes, smuggles;

- modern informative marketing system, aimed among all, at studying and forecasting the structure and directions of streams of people, goods and services across the border;

- logistic centre as coordinating body of all Ukrainian-Polish transport corridors.

Such logistic centre must include:

- transport networks for vehicles with facilities providing safety of traffic in these networks;

- boundary and custom posts;

- terminals and production areas, where the treatment of transit loads will be conducted (shifting works, storages, processing);

- system of the information (including logistic ) providing.

As the Polish east border became the east border of EU, the modernization of this border is the problem of not only Poland and Ukraine but also whole EU. The question is about the financial support of control pass points developing, their best technical equipping according to the EU standards, and the training of frontier services auxiliaries in both countries as well.

Due to the resources of EU within the framework of the PHARE, CBS, TACIS programs and European initiative INTERREG there was the conducted modernization of infrastructure on Ukrainian-Polish border, that promoted social and economic development of boundary regions, increase of environment protection, an adjusting of people contacts with the simultaneous prevention of marginalization of Poland's east provinces and western areas of Ukraine. 


\section{REFERENCES}

Bank danych regionalnych, GUS, <http://www.stat.gov.pl/bdr_n/app/strona.indeks >

Kowerski, M. and Matkowski, S. (2006), Gospodarka polsko-ukraińskiego regionu transgranicznego, Wiadomości Statystyczne, 2, 82.

Rocznik Statystyczny Województwa Podkarpackiego 2008, Urząd Statystyczny, Rzeszów, $<$ http://www.stat.gov.pl/cps/rde/xbcr/rzesz/ASSETS_08w22_01.pdf.>

Ruch przygraniczny Polska-Ukraina informacje i materialy wstępne. Statystyka publiczna dla rozwoju pogranicza Poludniowo-wschodniej Polski, Urząd Statystyczny, Rzeszów, <http://www.stat.gov.pl/rzesz/69_644_PLK_HTML.htm.>

World Economic Outlook Database, International Monetary Fund, October 2009, $<$ http://imf.org/external/pubs/ft/weo/2009/02/weodata/index.aspx.>

Data base "Regiostat", Golovne upravlinnâ statistiki u Lvivs'kij oblasti, <http://stat6. stat.lviv.ua/PXWEB2006p/dialog/statfile1_r.asp.>

Krol, M. and Krol, P. (2008), Scenarii rozvitku transkordonnogo spivrobitnictva pislâ vstupu Pol'ši do Evrosoûzu, Rzeszów, 46-52.

Mihasjuk, I., Zaloga, Z., Suhaj, O. (2008), Rozvitok transkordonnogo pidpriemnictva v ukraino-pol's'kih evro regionah, Lviv, 179-180.

Pol'ša-Ukraina: Investicijne spivrobitnictvo. Deržavna pidtrimka ukrainc'kogo eksportu, <http://www.ukrexport.gov.ua/ukr/analiz_inv_spivirobnictva/pol/341.html.>

Tokar, P. (2008), Novi realii sučasnih kordoniv. Sociologo-političnij analiz, KP “Užgorods'ka mis'ka drukarnâ, Užgorod, 26-33.

Fedan, R. (2008), Transkordonna i prikordonna infrastruktura, in: Social'noekonomične gurtuvannâ u konteksti modernizacii transkordonnih regioniv, Rzeszów 
http://rcin.org.pl 